\title{
Circulating Things, Circulating Stereotypes: Representations of Arabia in Eighteenth-Century Imagination
}

\author{
Ileana Baird
}

The fictions indeed of a poetical fancy are commonly as arbitrary as the stories of the vulgar are incredible and ridiculous; yet many traditionary fables, however wild and improbable they appear, are capable of being traced up to a very distant origin of truth.

Athenian Letters, Letter xxi, $1741^{1}$

In his History of the Decline and Fall of the Roman Empire (1776-1789), Edward Gibbon provides a description of Arabia that sums up the distinctive features of the place in the collective imaginary of eighteenth-century British subjects:

"The Arabian Peninsula contains the vacant space between Persia, Syria, Egypt, and Æthiopia; and the entire surface of it exceeds in a fourfold proportion that of Germany, or France; but the far greater part of it has properly acquired the epithets of the stony and the sandy. In the dreary waste, a boundless level of sand is intersected by sharp and naked mountains. The winds diffuse a noxious, and even deadly vapour; the hillocks of sand which they alternately raise and scatter have buried whole caravans, and even armies; destitute of navigable rivers, the refreshment of water is precariously to be enjoyed by the Arabian traveler; and a scanty supply of rain is collected for its use in cisterns and aqueducts. But the high lands that border on the Indian Ocean are distinguished by

1 Athenian Letters: Or, the Epistolary Correspondence of an Agent of the King or Persia, Residing at Athens during the Peloponnesian War. Containing the History of the Times, in Dispatches to the Ministers of State at the Persian Court. Besides Letters on Various Subjects between Him and His Friends (London: Printed by James Bettenham, 1741), 1:80. their superior plenty; wood and water freely present themselves; the air is more temperate; the fruits more delicious; the animals and the human race more numerous; the peculiar gifts of frankincense and coffee have attracted, in different ages, the merchants of the world; and this part of the peninsula, contrasted with the stony and the san$d y$, has been honored with the epithet the happy."

The space is described as a summa of striking opposites: the "dreary waste" and "boundless sand" are contrasted here to the abundance of wood, water, and "gifts" of trade; the "deadly vapours" brought by harsh winds are juxtaposed to the reviving scents of frankincense and coffee; and the "precarious" and "scanty" rains are counterbalanced by a "plenty" of fruit, animals, and inhabitants in the mountainous areas. The death trope contained in the image of the "buried" caravans is opposed to the trope of bountiful life suggested by the thriving commerce that characterizes the southern area of the peninsula. While Arabia the stony and Arabia the sandy are afflicted by a harsh environment and a lack of natural resources, Arabia the happy has a "more temperate" climate and is rich in products that attract merchants to its shores (fig. 4.1). ${ }^{3}$

Gibbon's description of the Arabian Peninsula through the things that stand for this place is

2 The quote comes from an early reprint of Gibbon's History of the Decline and Fall of the Roman Empire, Abridged in Two Volumes (London: Printed for A. Strahan and T. Cadell, 1790), 2:250-51.

3 Gibbon's description follows that of Ptolemy's, who was the first one to refer to the three Arabian provinces as Arabia the Stony, Arabia the Desert, and Arabia the Happy. 


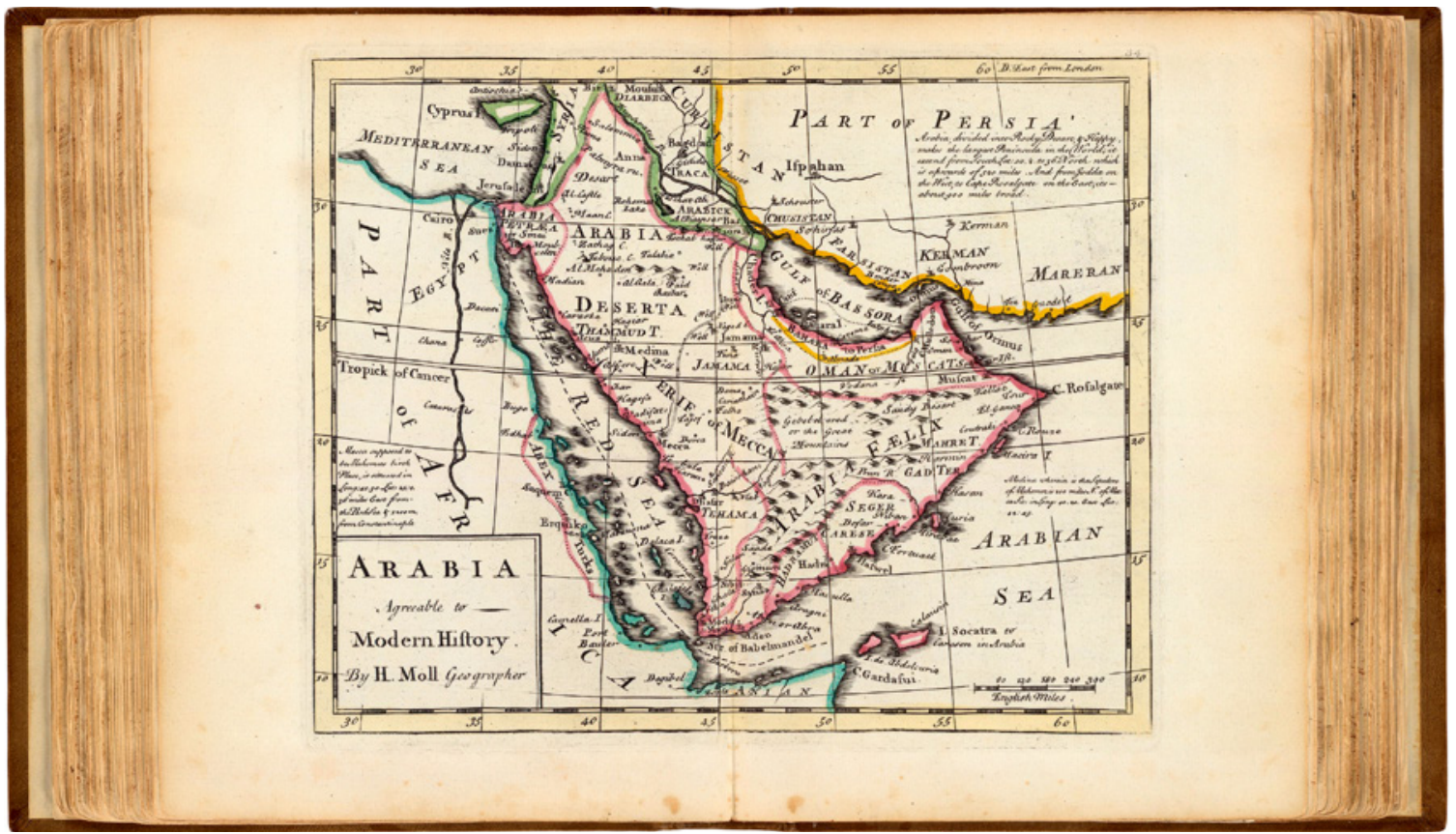

FIgURE 4.1 H. Moll, Arabia. Agreeable to Modern History, Cornhill, 1736(?)

symptomatic of the century's redefinition of the other spaces in ways that often give rise to stereotypes, standardized mental pictures or, to use Edward Said's words, "imaginative geographies" that coalesce into simplified opinions and prejudiced attitudes toward the other. ${ }^{4}$ Said's argument is well-known: during the Oriental stage, a period roughly placed between 1765 and 1850,5 "the Orient, and in particular the near Orient, became known in the West as its great complementary opposite" 6 in a process of ideological redefinition

4 Edward W. Said, Orientalism (New York: Vintage Books, 1979), 49 .

5 See Raymond Schwab, La Renaissance orientale (Paris: Payot, 1950), qtd. in Said, Orientalism, 51. Said also discusses two more meanings of Orientalism. As a field of study, he argues that Orientalism commenced in 1312 with the decision of the Church Council of Vienna to establish Chairs in Arabic, Greek, Hebrew, and Syriac in Paris, Oxford, Bologna, Avignon, and Salamanca. As a "style of thought," or imaginative construct of the Orient, Orientalism permeates all fields of knowledge up to this day (2).

6 Said, Orientalism, 58 . he famously described as "orientalizing the Oriental."7 This process employs the same binary opposites so effectively used by Gibbon in his description to suggest a hierarchy of value: while "Europe is powerful and articulate," "Asia is defeated and distant"; the "European superiority" is contrasted to the "Oriental backwardness." ${ }^{8}$ As a European invention, the Orient is "a place of romance, exotic beings, haunting memories and landscapes, remarkable experiences," ${ }^{9}$ a space both vague and alluring that crams within its loose boundaries the wildest fantasies of the West.

It is my intention here to challenge some of these interpretations by exploring the mechanism of stereotyping in relation to the Arab world as mediated by the things that represented this space during the eighteenth century. I am particularly interested in understanding the process of stereotyping outside a colonial lens and outside a political

\footnotetext{
7 Ibid., 49 .

8 Ibid., 7 .

9 Ibid., 1.
} 
rendering of the stereotype. As Gibbon correctly pointed out, " $[\mathrm{t}]$ he transient dominion obtained by the Abysinians, the Persians, the sultans of Egypt, and the Turks over the kingdom of Yemen, has not precluded the Arabs from the praise of perpetual independence."10 Arabia was not a Western colony during the eighteenth-century, nor did it occupy a fully subservient position in relation to Western civilizations later on, so the power binaries employed by postcolonial readings do not work well when describing Arabia's relationship with the West. Unlike other colonized territories, the Arabian Peninsula benefitted from the flourishing trade in spices, coffee, dates, perfumes, pearls, and medicines it facilitated as one of the main trade routes between Europe and Asia. Moreover, during the eighteenth-century these commercial exchanges were accompanied by cultural ones. During the time, Arabia started to occupy a distinctive place in the Western imaginary due to a book that, as Saree Makdisi and Felicity Nussbaum argued, "changed the world on a scale unrivalled by any other literary text": 11 Antoine Galland's translation of Les mille et une nuits between 1704-1717 and its subsequent translation in English as Arabian Nights' Entertainments between 1706-1721 created an immensely influential, albeit inaccurate, representation of "Arabia" from this point on, which will further complicate the process of cultural transmission and interaction between the Arabian Peninsula and the Western world.

Given these unique circumstances that define the contact between Arabia and Europe during the eighteenth century, unique sets of questions arise. What taxonomies are in place when the relationships between the two areas do not involve imperial vs. colonial binaries? How did the Arabian things contribute to the formation of an Arabian identity? What can a "reinjection of things into our

\footnotetext{
10 Gibbon's History, 2:253.

11 Saree Makdisi and Felicity Nussbaum, introduction to The Arabian Nights in Historical Context: Between East and West, ed. Saree Makdisi and Felicity Nussbaum (Oxford: Oxford University Press, 2008), 1.
}

understanding of the social fabric"12 reveal about the networks of exchange-commercial, cultural, and not only-developed between Arabia and the Western world during the Enlightenment? Finally, how accurate were these stereotypes in their time and how relevant are they today? As this chapter will argue, the rendition of Arabia during the eighteenth century is heavily reliant on things - both real and fictional-that represent this place in the Western imaginary. These representations have often led to sets of stereotypes which, when describing Arabia itself and not one of its misnomers, function very differently than the stereotypes that stem from a colonial discourse.

\section{Representing Arabia: Things and Place}

Given Arabia's strategic position at the confluence of the trade routes between East and West, numerous stereotypes about its immense riches and abundance of goods started to emerge during the Age of Reason. In the Spectator No. 69 [The Royal Exchange], Joseph Addison mentions at least four commodities intensely associated with the Arab Peninsula: scarves, spices, oils, and silks. ${ }^{13}$ Similar references are abundantly found in the scientific, instructional, and literary productions of the time. In the Athenian Letters (1741-1743), for instance, Arabia the Happy is described as "one universal altar ever breathing forth spontaneous incense to the heavens," and as a place where "the sweet effluvia are wafted by the winds and spread a grateful Fragrance for many miles beyond the coasts." So many cassia and other odoriferous plants are along the Arabian shores that they "perfume the air with a strange variety of healthful and pleasant scents."14 A 1745 Collection of Voyages and Travels similarly mentions the abundance of "things precious and

\footnotetext{
12 Bruno Latour, "On Actor-Network Theory. A Few Clarifications," Soziale Welt 47, no. 4 (1996): 369-81.

13 Joseph Addison, The Spectator, 8 vols. (London: Printed for S. Buckley and J. Tonson, 1712), 1:48.

14 Athenian Letters, 1:80.
} 
aromatic," such as "frankincense and myrrh, palmtrees, cinnamon, cassia, and lignum-aloe," whose smell is so sweet that they "seemeth rather to be heavenly, than earthly." ${ }^{15}$ References to the spices of Arabia appear in Samuel Johnson's Rambler 120 ["The History of Amamoulin, the Son of Nouradin"], as well as in his Dictionary (1750), where he lists several things coming from the Arab world: assa foetida ("a gum or reisin of a sharp taste and a strong offensive smell ... of known efficacy in some uterine disorders"), the balsam tree (whose blossoms are "like small stars, white and very fragrant"), and the bdellium ("a tree ... which yielded a certain gum sweet to smell"). ${ }^{16}$ In his Compendious Geographical and Historical Grammar (1795), John Mair indicates that " $\mathrm{t}]$ he produce of this country is principally aloe, cassia, spikenard, frankincense, myrrh, mana, and other costly gums,"17 and in Lex Mercatoria Rediviva (1792), Wyndham Beawes mentions fragrances like "Incense, Balsam, Myrrh, and Calamus Aromaticus" as originating from Arabia. ${ }^{18}$ Finally, maybe the most famous eighteenthcentury reference to Arabic things, Alexander Pope's description of Belinda's dressing table in

15 A Collection of Voyages and Travels, Consisting of Authentic Writers in Our Own Tongue, Which Have Not before Been Collected in English, or Have Only Been Abridged in Other Collections, 2 vols. (London: Printed for and sold by Thomas Osborne of Gray's-Inn, 1745), 1:620.

Samuel Johnson, A Dictionary of English Language; in Which the Words Are Deduced from Their Originals and Illustrated in Their Different Significations by Examples from the Best Writers. To Which Are Prefixed, a History of the Language, and an English Grammar, 2 vols. (London: Printed by W. Strahan, 1755), 1: n.p.

John Mair, A Compendious Geographical and Historical Grammar Exhibiting a Brief Survey of the Terraqueous Globe. And Shewing the Situation, Extent, Boundaries, and Divisions of the Various Countries; Their Chief Towns, Mountains, Rivers, Climates, and Productions; Their Governments, Revenues, Commerce, and Their Sea and Land Forces... (London: Printed for W. Peacock, 1795), 42

18 Wyndham Beawes, Lex Mercatoria Rediviva: Or, A Complete Code of Commercial Law (London: Printed for R. Baldwin et al., 1792), 23.
The Rape of the Lock (1712-1714/15) includes a reference to the exquisite perfumes that stand, metonymically, for Arabia itself: “This casket India's glowing gems unlocks, / And all Arabia breathes from yonder box." ${ }^{19}$ The place is reduced to a thing of ephemeral beauty, to a signifier, or stereotype, that encapsulates the very essence of Arabia in the Western imaginary: its highly sought-after, thoroughly expensive, intoxicating scents.

Not only perfumes and aromatics but also spices and exotic foods were commonly associated with the area. In a 1790 Geography and History textbook by "a Lady" "for the use of her own children," Arabia the Happy is described as being "blessed with an excellent soil, and very fertile, and produces many valuable gums, fruits, honey, and wax; and is particularly famous for its coffee and dates." ${ }^{20}$ Mair's survey also indicates that "cinnamon, pepper, cardamom, dates, figs, oranges, lemons, pomegranates, and other fruits; likewise honey and wax" can be found in Arabia "in great plenty." ${ }^{21}$ Carsten Niebuhr's Travels through Arabia (1792) mention gum Arabic, saffron, and dates as staples of the place. ${ }^{22}$ "The sweets of Arabia calm sickness and pain,"23 according to Mary Robinson's "Pastoral Stanzas" and, as suggested in "An Epistle from Mr. Pope to Mr. Gay," they stand out for their unique fragrance. ${ }^{24}$ Similarly, a note from Vathek (1786)

19 Alexander Pope, The Rape of the Lock, ed. Cynthia Wall (Boston: Bedford Books, 1998), 57.

20 Geography and History. Selected by a Lady, for the Use of Her Own Children (London: Printed for B. Law, 1790), 157 .

Mair, A Compendious Geographical and Historical Grammar, 42.

Cartsten Niebuhr, Travels through Arabia, and Other Countries in the East, trans. Robert Heron (Edinburgh: Printed for R. Morison and Son, 1792), 1:24, 99, and 190, respectively.

23 Mary Robinson, Poems (London: Printed by J. Bell, 1791), 166.

24 Miscellanea. In Two Volumes. Never before Published. Viz. I. Familiar Letters Written to Henry Cromwell Esq. by $\mathrm{Mr}$. Pope. II. Occasional Poems by Mr. Pope, Mr. Cromwell, Dean Swift etc. III. Letters from Mr. Dryden, to a Lady, in the Year 1699 (London: Printed for E. Curll, 1727), 1: 135. 
indicates the use of balsam, which is "indigenous in various parts of Arabia," as an ingredient in the "Myrabolan comfit." ${ }^{25}$ Such references emphasize Arabia's exoticism and refined taste, as well as the sweetness and fragrance of its products, which were much valued during a time when the consumption of sugar and spices was rising rapidly among European populations.

Coffee is another staple thing customarily associated with the area. In his Dictionary, Johnson indicates the Arabic origin of coffee and rightly so, as one the most popular types of coffee is called "Arabica" because it was first domesticated for commercial use in the southern part of Arabia the Happy (present-day Yemen). Given the Muslim prohibition of alcohol, coffee became particularly attractive to the Muslim world as "the wine of Islam," 26 and spread through the ports of the Persian Gulf in Western Europe, where it became immensely popular. Collections of travels published during the time mention that coffee was "the product of Arabia only."27 Imported largely from Yemen, which was credited with producing the best coffee in the world, coffee was considered to have stimulating and therapeutic properties. ${ }^{28}$ The former quality is famously described by Pope in The Rape of the Lock: "Coffee (which makes the politician wise), / And see thro' all things with his half-shut Eyes) / Sent up in vapours to the Baron's brain / New Stratagems, the radiant Lock to gain." ${ }^{29}$ According to Beawes, the product was brought to Mecca through the port of Jeddah, whose "[t]rade consists mainly of coffee brought here by the Arabians and bought by the

25 Wiliam Beckford, An Arabian Tale, from an Unpublished Manuscript: With Notes Critical and Explanatory (London: Printed for J. Johnson, 1786), 165.

For the association between coffee and wine, see Ralph S. Hattox, Coffee and Coffeehouses: The Origins of a Social Beverage in the Medieval Middle East (Seattle: University of Washington Press, 1985), 18-19.

28 Coffee was customarily used as a mild painkiller during the eighteenth century. Poet Alexander Pope, for instance, used it as a palliative for his migraines.

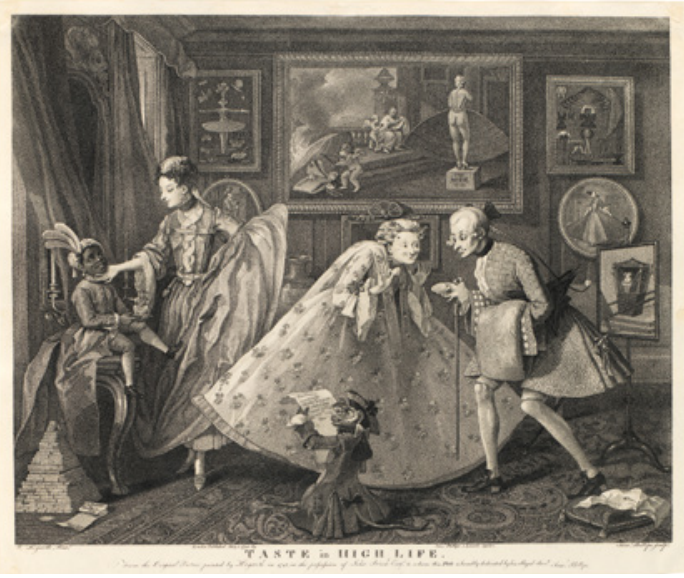

FIGURE 4.2 William Hogarth, Taste in High Life [graphic]. PRINT MADE BY ISAAC MILLS AFTER WILLIAM HOGARTH'S PAINTING, WITHOUT THE ARTIST'S PERMISSION, LONDON, 1798

Turks ... [and] by the Merchants of Mogul, Persia, and several places on the coast of Ehiopia." ${ }^{30}$ From here, coffee spread rapidly in England, France, and Italy, giving rise to the coffeehouse culture that is a hallmark of the eighteenth century. Coffee was also regularly paired in the visual culture of the time with expensive china (fig. 4.2), was employed as a mark of the culture of sociability (fig. 4.3), or was used for its oracular properties ${ }^{31}$ (fig. 4.4).

Arabian medicines were also much sought-after in the Western world. As indicated by Beawes, "from Arabia, Medicinal drugs, Dragon's Blood, Manna, Myrrh, [and] Incense,"32 were brought to the British metropolis. Pharmacopoia Reformata (1744) mentions gum Arabic, aloe, cassia, acacia, cardamom, saffron, myrrh, and spikenard, which were all used for their therapeutic properties. ${ }^{33}$ To

$30 \quad$ Beawes, Lex Mercatoria Rediviva, 791.

31 Again, the custom of reading one's fortune in coffee grounds is of Turkish provenance, not Arabic. Such mistaken attributions were pervasive during the eighteenth century. Beawes, Lex Mercatoria Rediviva, 792.

33 M.M., Pharmacopoia Reformata: Or, An Essay for a Reformation of the London Pharmacopoia, by a Set of Remarks on the Draught for a New One, and a Brief Account of the Proceedings of the Committee Appointed by the College of Physicians, to Thoroughly Reform Their 


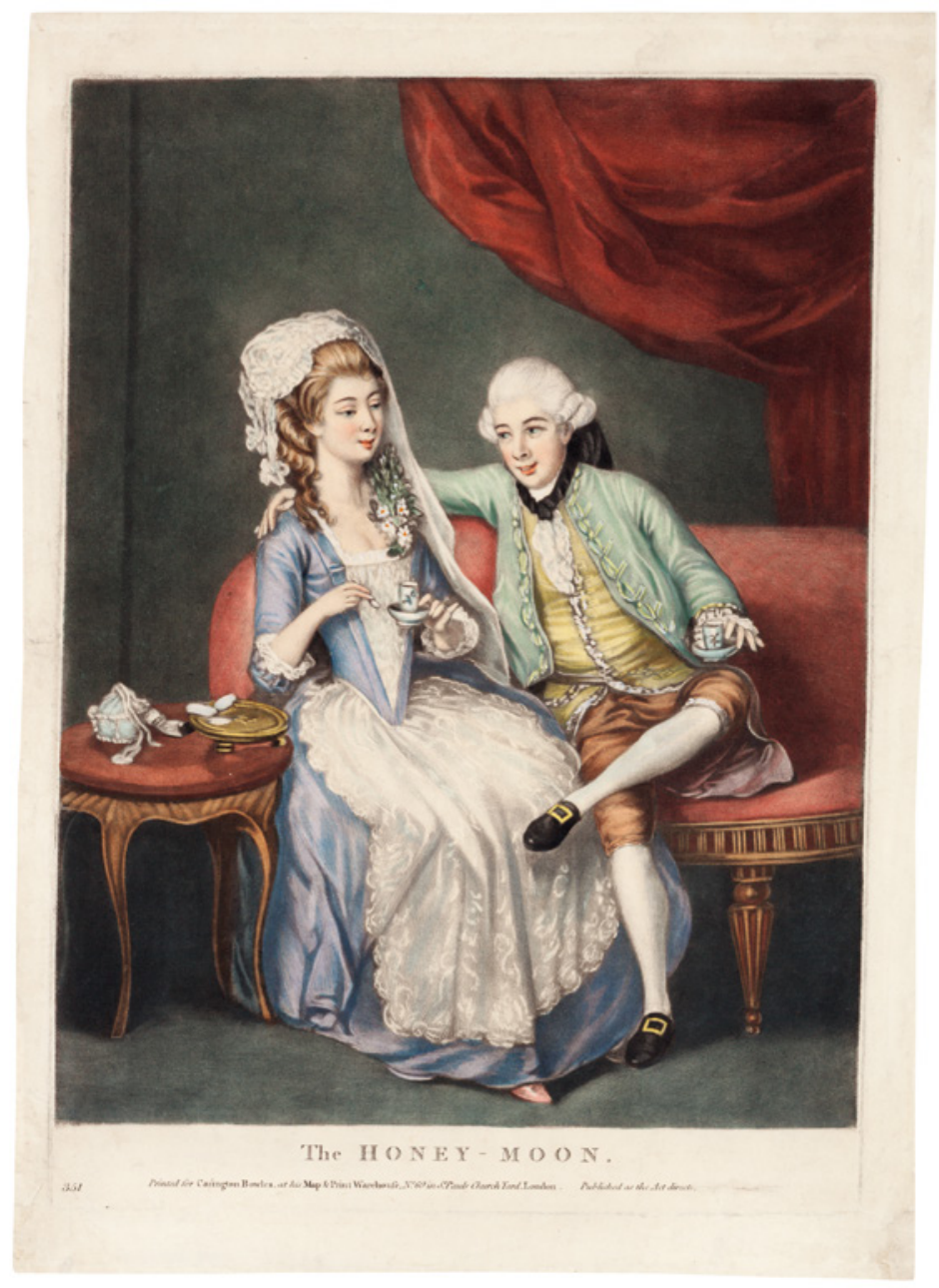

FIGURE 4.3

The Honey-Moon [graphic]. Mezzotint, hand-colored. PRINTED FOR CARINGTON BOWLES, LONDON, JUNE 1777

this list, Richard Walker, apothecary to the Prince of Wales, adds Arabic henna, manna, and rhubarb. ${ }^{34}$ The influence of the Arabian medicine first on the Greek, then on the French and English physicians, although often decried, brought an influx of medicinal plants from or through the Arabian

Book. Interspersed with Some Occasional Observations on Some of the Most Celebrated Modern Dispensatories, and the Present State of Pharmacy (London: Printed and Sold by R. Willock, 1744). This volume contains a wealth of detailed recipes for various afflictions, albeit providing few specifics as to what was treated by using them.

34 Richard Walker, Memoirs of Medicine; Including a Sketch of Medical History from the Earliest Accounts to the Eighteenth Century (London: Printed for J. Johnson, 1799).
Peninsula to Europe, where they were customarily used in tinctures, purges, and other more or less effective elixirs. ${ }^{35}$ Alternately, incense was used for its love-inducing and rejuvenating properties, as seen in an 1787 etching by James Gillray representing a group of five elderly women of fashion attending an altar of Love (fig. 4.5). ${ }^{36}$

35 For the influence of the Arabian medicine on Western Europe, see volume 3 of John Astruc's Treatise on the Diseases of Women, in Which Is Attempted to Join a Just Theory to the Most Safe and Approved Practice... (London: Printed for J. Nourse, 1767). For detailed recipes of medicines containing ingredients of Arabic origin, see Pharmacopoia Reformata cited above.

36 Arabian incense is made by using frankincense or gum Arabic resin mixed with sweet-smelling essential oils, such as myrrh and oud. 


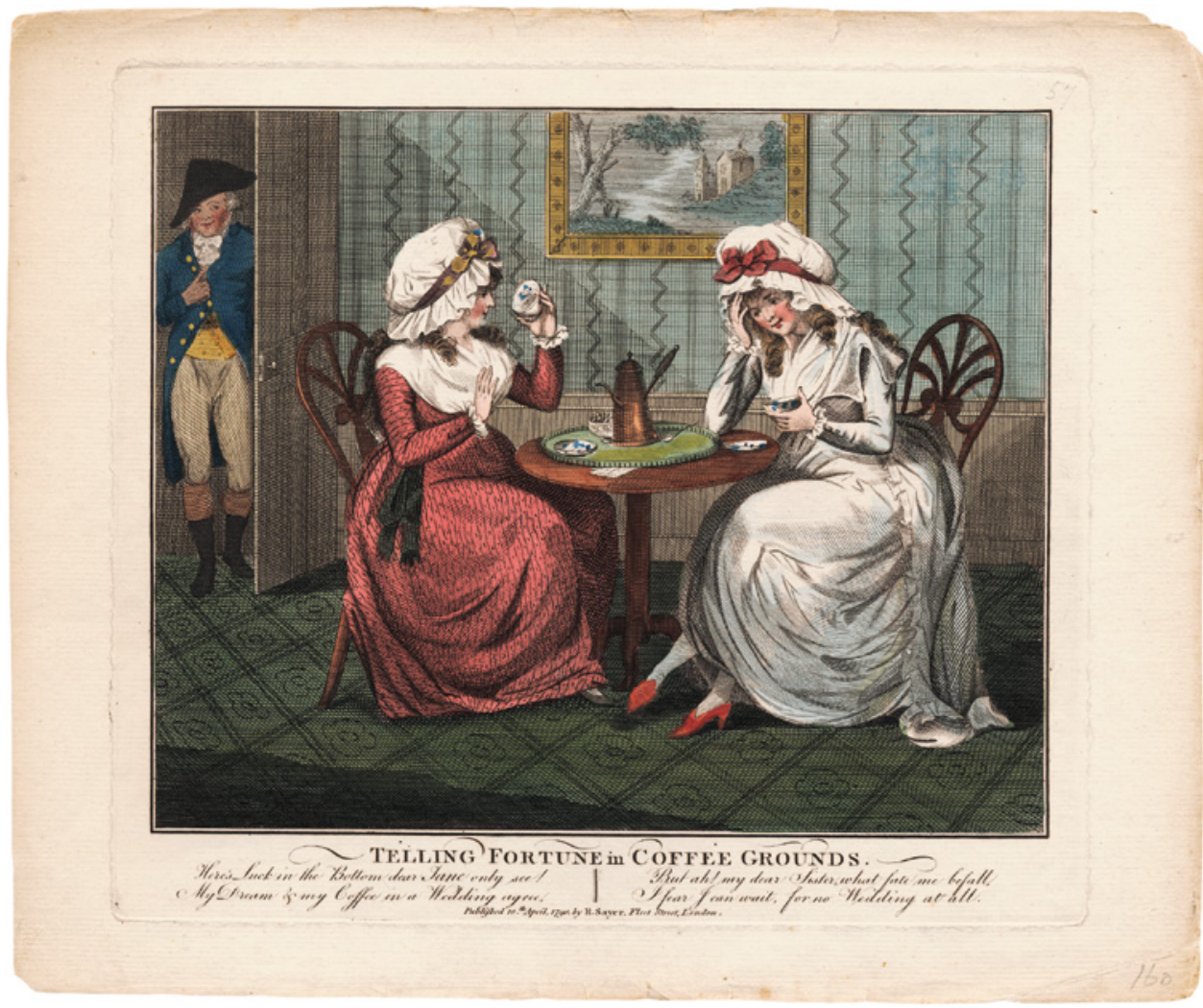

FIGURE 4.4 Telling Fortune in Coffee-Grounds [graphic]. PUBLISHED BY ROBERT SAYER, LONDON, 1790

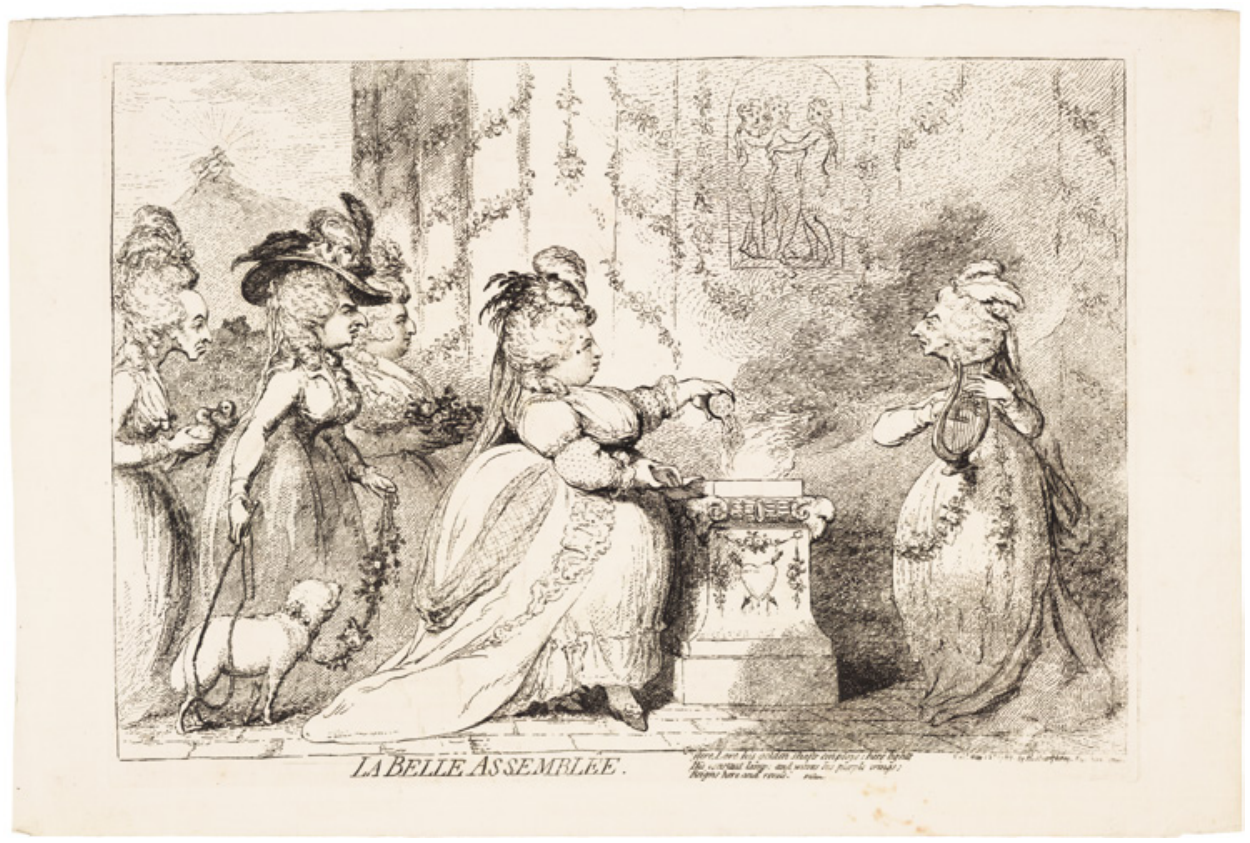

FIGURE 4.5 James Gillray, La belle assemblée [graphic]. Etching with stipple on laid paper. PUBLISHED BY H. HUMPHREY, LONDON, 1787 
The stereotypical representation of the Arabian Peninsula as a bearer of many "riches," a surprising descriptor given the bareness of most of the area, is likely to have originated from the trade in "Turquoises and Pearls," 37 as well as ivory, gold, cornelian, and other valuables which were trafficked by the Arab merchants during the time. As mentioned in A Collection of Voyages and Travels, the place abounded in "raisins, dates, gold, ivory, and slaves" [emphasis added] which the Arabs bartered "for small cloths of diverse sorts and colours." ${ }^{38}$ In turn, Mair mentions that "[i]n their seas are found coral, pearl, and a species of cornelian which is much esteemed, because it is easy to be engraved upon."39 Pearls were harvested in an area extending from the present-day coastal Saudi Arabia to Dubai, Bahrain, Kuwait, and Qatar. The Bahrain pearl market was the most important in the region, followed in the second half of the century by new centers in Kuwait, Abu Dhabi, and Zubara. ${ }^{40}$ In his Travels through Arabia, Niebuhr mentions that Kuwaitis were making a living from the fishery of pearls, for which they employed "more than eight hundred boats,"41 while Bahrain had "the best pearls"42 in the Persian Gulf. Similarly, Beawes remarks that pearl fishery in the Persian Gulf island of Barbarem "produces at least a Million [pearls] yearly," many of them of "a Large Size ... even to a Weight of fifty Grains." ${ }^{33}$ In Nature

37 Beawes, Lex Mercatoria Rediviva, 792.

38 A Collection of Voyages and Travels, 620.

39 Mair, A Compendious Geographical and Historical Grammar, 42.

40

By the beginning of the nineteenth-century, the Gulf area became the major global supplier of natural pearls. The high quality "Oriental" pearls were much sought-after by the great jewelry houses of Europe. For details, see Robert Carter, "The History and Prehistory of Pearling in the Persian Gulf," Journal of Economic and Social History of the Orient 48, no. 2 (2005): 139-209, and Sea of Pearls: Arabia, Persia, and the Industry That Shaped the Gulf (London: Arabian Publishing, 2012), 109-40.

$41 \quad$ Niebuhr, Travels through Arabia, 2:127.

42 Ibid., 2:152.

43

Beawes, Lex Mercatoria Rediviva, 792.
Display'd (1763), Noël Antoine Pluche mentions "the Gold of Arabia" and "the Pearls of Katif" 44 as identifiers of the place while in Geographical Dictionary (1800) Clement Cruttwell indicates that Arabia had "the best coral and pearls" in the world. ${ }^{45}$ The use of pearls for adornment was widespread at both the Asian and Western European courts, bearing connotations of nobility, purity, wealth, and exoticism, as often seen in the visual culture of the time (figs. 4.6 and 4.7).

Camels and Arabian horses are other emblematic things customarily associated with the place. ${ }^{46}$ Johnson mentions the camel as a representative animal of the place in his Dictionary and, in The Prince of Abissinia (1759), he remarks that the Arabs' "only wealth is their flocks and herds." 47 "The camel is in Arabia ... a beast of burden, that helps to carry off its spices," explains Addison through the voice of Philander, who goes on to cite Dryden's lines about "the tir'd camel's back," carrying "pepper and Sabaean incense." ${ }^{48}$ According to Mair's account, "camels, which are very numerous, are of singular use for

Noël Antoine Pluche, Spectacle de la nature; or, Nature Display'd (London: Printed for R. Francklin et al., 1763), 6:53.

Clement Cruttwell, The New Universal Gazetteer; Or, Geographical Dictionary: Containing a Description of All the Empires, Kingdoms, States, Provinces, Cities, Towns, Forts, Seas, Harbours, Rivers, Lakes, Mountains, and Capes; the Extent, Boundaries, and Natural Productions of Each Country; the Trade, Manufactures, and Curiosities of the Cities and Towns, Collected from the Best Authors; Their Longitude, Latitude, Bearings, and Distances Ascertained by Actual Measurement, on the Most Authentic Charts. Together with an Atlas, Containing Twenty-Six Whole-sheet Maps (Dublin: Printed and Sold by John Stockdale, 180o), 28.

Johnson, A Dictionary of English Language, 1:n.p. Johnson also mentions "cilicious," "a garment of camel's hair; that is, made of some texture of that hair, a coarse garment ... suitable to the austerity of [an Arab's] life." Samuel Johnson, The Prince of Abissinia. A Tale. In Two Volumes (London: Printed for R. and J. Dodsley, 1759), $1: 63$.

Joseph Addison, Dialogues upon the Usefulness of Ancient Medals, Especially in Relation to the Latin and Greek Poets (Glasgow: Printed by R. Urif, 1751), 167. 


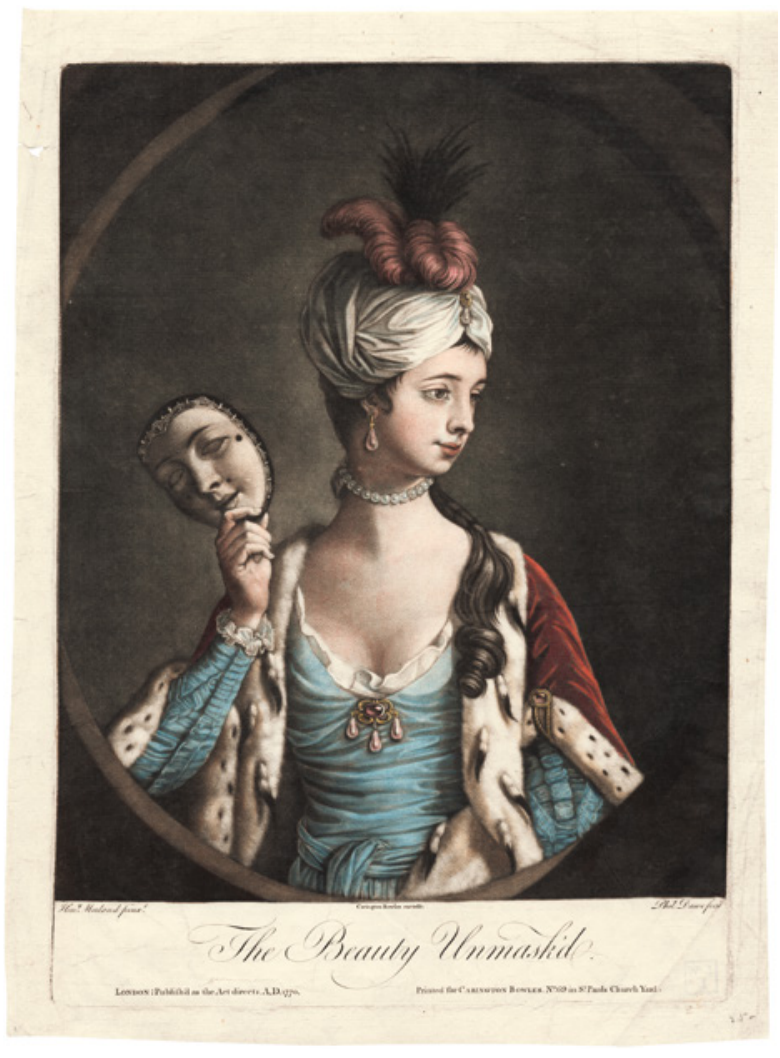

FIGURE 4.6 Phillip Dawe, The Beauty Unmask'd [graphic]. Mezzotint, hand-colored. PRINTED FOR CARINGTON BOWLES, LONDON, 1770

carriage, especially for the caravans," and "seem to be formed by Providence in a more special manner for the sultry and dry soil of Arabia where no water is to be found in a journey of several days over the sandy desarts [sic]." ${ }^{49}$ These comments echo other accounts of the time that detail the multifarious use of Arabia's camel, such as The Wonderful Magazine, a weekly entertainer, which reports: "[t]he milk of the camel nourishes the family of the Arab under the varied forms of curd, cheese, and butter; and they often feed upon his flesh. Slippers and harness are made of his skin; tents and cloathing of his hair." ${ }^{50}$ Similarly, Gibbon describes the camel as

49 Mair, A Compendious Geographical and Historical Grammar, 42.

50 The New Wonderful Magazine, and Marvellous Chronicle: Or, New Weekly Entertainer. A Work Recording Authentic Accounts of the Most Extraordinary Productions,

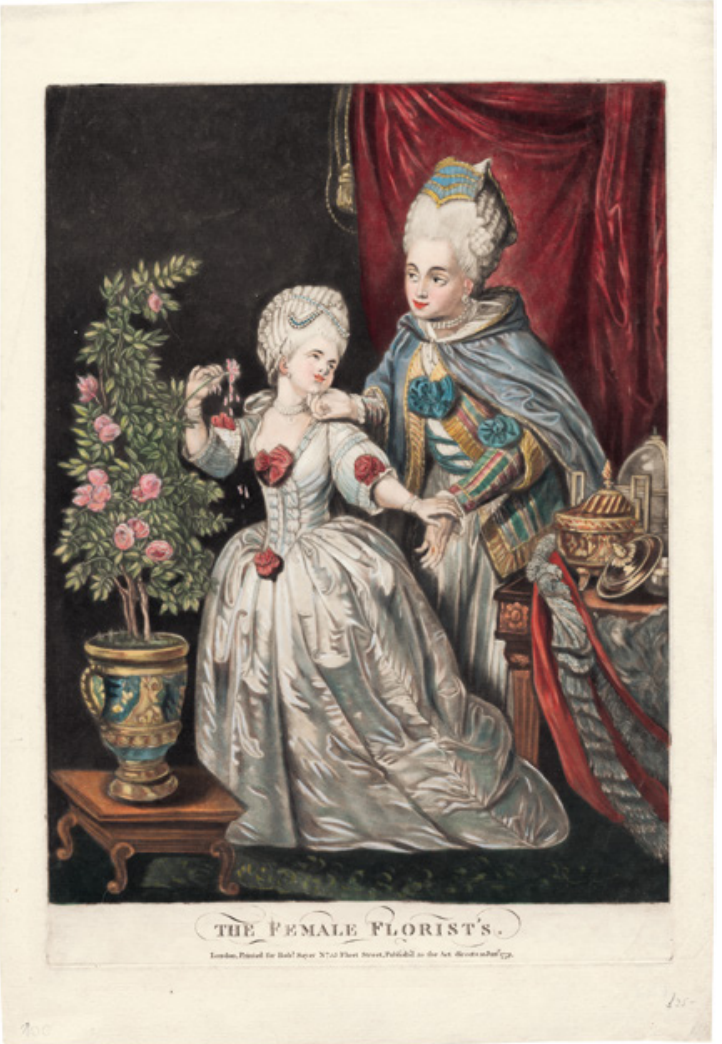

FIGURE 4.7 The Female Florist's [graphic]. Mezzotint, hand-colored. PRINTED FOR ROBERT SAYER, LONDON, 1773

"strong and patient," and "capable of performing, without eating or drinking, a journey of several days." Moreover, "almost every part, alive or dead, is serviceable to man. The milk is plentiful and nutritious; the young and tender flesh has the taste of veal; a valuable salt is extracted from the urine; the dung supplies the deficiency of fuel; and the long hair, which falls each year, and is renewed, is coarsely manufactured into the garments, the furniture, and the tents of the Bedweens." ${ }^{11}$ The beast's thingness is, thus, suggestively emphasized by its description as a collection of parts, each of them fulfilling a particular function for the subject, and supports its fundamental role in the life of the Beduin population. As regards the Arabian horses, they were wide-

Events, and Occurrences, in Providence, Nature, and Art (London: Printed for the Proprietors, 1794), 5:16. 
ly acknowledged as "the best in the world,"52 being "much admired" 53 by locals and travelers alike. According to Gibbon, " $[\mathrm{t}]$ he Bedweens preserve, with superstitious care, the breed and pedigree of the horse" whose original country of origin is Arabia. ${ }^{54}$ As mentioned in The World Displayed (1795-1796), a selection of travel narratives by several hands, " $[\mathrm{t}]$ he Portuguese ... get supplies of rice here ... and bring back in return horses, dates, pearls and other merchandise of the produce of Arabia" ${ }^{55}$ [emphasis added]. As the eighteenth-century horse breeder Richard Wall explains, the Yemeni horses "are often sold for four hundred and some of the finest of them for five hundred guineas a horse" to Persian and Indian nobility. ${ }^{56}$ First brought to England for breeding during the eighteenth century, Arabian horses were much valued for their beauty, noble bearing, resilience, and speed. ${ }^{57}$ Such accounts suggestively illustrate various aspects of the everyday life of the local populations, their intense commerce with the rest of the world, and the important identification

52 A Collection of Voyages and Travels, 620.

53 Geography and History, 158.

54 Gibbon's History, 2:252.

55 The World Displayed: Or, A Curious Collection of Voyages and Travels, Selected and Compiled from the Writers of All Nations by Smart, Goldsmith, \& Johnson (Philadelphia: Published by Dobelbower, Key, and Simpson, 1795-1796), 4:147.

Richard Wall, A Dissertation on Breeding of Horses, upon Philosophical and Experimental Principles; Being an Attempt to Promote Thereby an Improvement in the Present Manner of Breeding Racers, and Horses in General. Also Some Material Observations upon Those Sorts of Foreign Horses, Which Are Adapted to Racing; Particularly Those of the Kingdom of Yemine, in Arabia Fcelix, or South Arabia. Also Those of Arabia Petrea, or North Arabia. And Likewise Those of Barbary, Turky, and Ethiopia. In a Letter to a Friend (London: Printed for G. Woodfall, 1760 ?), 75 .

During the eighteenth century, the Darley Arabian, Byerly Turk, and Godolphin Arabian, which were the three foundation stallions of the modern Thoroughbred breed, were brought to England for the first time. For details, see Rosemary Archer, The Arabian Horse (London: J.A. Allen, 1992), 104-09. of product and place (“Arabian" or "Yemeni” horses) when the former is imbued with extraordinary value.

Among other things typically associated with the Arabian Peninsula, one can recognize the gilded slippers, the turban, the veil, the long gowns, the hookah, and the tobacco. A spicy footnote to the "Original Dedication" to The Tatler tells the story of the second son of Lady Mary Wortley Montagu, Edward, who "became so enamored of the dress and manners of Arabia" that "he sat in his ... dress, squat, after the eastern fashion, to regale himself with smoaking [sic] tobacco and drinking coffee," leaving upon his sudden death "several widows behind him." 58 In his Travels, Niebuhr mentions the Arabs' fondness for coffeehouses where they "maintain a profound silence ... [and] prefer conversing with their pipe. ${ }^{59} \mathrm{He}$ also provides details on the "beautiful simplicity of the eastern dress," 60 and explains that the veil is "the most important piece" of Arab women's clothing, as "their chief care is always to hide their face." ${ }^{61}$ Although their modesty prevents them from revealing themselves, Arab women are very fond of adornments, which include earrings, ankle and arm bracelets, and bells, and they "paint their hands yellow, and their nails red, fancying these whimsical colourings irresistible charms." 62 Niebuhr's Travels is an early source that documents the use of henna as a means of embellishing the body, a practice with Egyptian origins that is widely spread in the Arabian Peninsula to this day, so it has a clear documentary value. What makes such narratives significant, however, is, first, that they depict less a place than a lifestyle (the more relaxed, more sensual,

$5^{8}$ The Tatler (London: Printed by Rivington, Marshall and Bye, 1789), 2: iii-iv. The scene, although located in "Arabia," actually took place in Turkey, a place visited by Lady Mary Wortley Montagu. Her travel accounts were immensely popular during the eighteenth century. Niebuhr, Travels through Arabia, 1:126.

$60 \quad$ Ibid., 1:24.

61 Ibid., 1:118.

62 Ibid., 1:118-19. 
and more contemplative, "Eastern" approach to life), and, second, that they conflate under the term "Arabia" or "Arab" various fashions, establishments, or customs belonging to areas extending from Egypt to Turkey and everything in between. The "Arabian" things speak, in other words, of the complex entanglement of multiple cultures in the identity formation of "Arabia" by an eighteenthcentury subject.

Such accounts, most of which originated from travelers and traders coming in direct contact with the local populations, offer more or less accurate descriptions of the Eastern things and of the customs associated with them which, as we will see, compete with alternative, fictional narratives about the place. Interestingly, the inaccuracies one may find in such accounts-such as certain commodities originating from Arabia-are in most cases self-generated by the local merchants, who exaggerated the difficulties or dangers they encountered in acquiring these products in order to increase their sale value. This practice is discussed by Beawes in relation to some "Arabian" spices, such as cassia or cinnamon, about which "Arab merchants invented fables or pretended difficulties" in procuring them, "which made all Antiquity believe that these Spices or Aromatics were scarce and only to be found in Arabia." ${ }^{3}$ Whether using correct descriptors of the place, such as "immense sands," 64 caravans, palm trees, camels, and dates or, on the contrary, inaccurate attributions, such as exotic animals, spices, fruits, and precious metals, these accounts depict the things of the trade and the things of the imagination as intersecting, again and again, on ideas of wealth, danger, and exoticism.

\section{Orientalizing Arabia: Mistaken Identity}

One of the main difficulties encountered by scholars involved in the study of the Arabian

63 Beawes, Lex Mercatoria Rediviva, 15.

64 Geography and History, 158. culture in general, and of the Arabian culture of the eighteenth century in particular, is what Janice J. Terry called "mistaken identity":65 the proliferation of fallacious representations of the Middle East that often involve blurry spatial identifications. Indeed, there is a lot of uncertainty of what an "Arab" and, through extension, what an "Arabic" or "Arabian" denomination encompass, both historically and geographically. Many eighteenthcentury accounts use "Arabian" as an umbrella term for cultures that have little to do with the Arabian Peninsula or with Arabs themselves. At the time, the term "Arabian" was quite capacious and included, undistinguishably, "Arabian Persians," Syrians, Ottomans, Egyptians, and a whole host of Muslim populations from northern Africa and the Far East. This mistaken attribution has several reasons. First, many eighteenth-century accounts use the language and the religion of the populations in these areas as stronger identifiers than their geographical location, which was quite fluid at the time; in this sense, an "Arab" is a speaker of Arabic or a believer in Islam. The complicated history of the area and the spread of the Arabic language through the Arab conquests of the seventh and eight centuries to regions extending from the confines of Tartary and India to the shores of the Atlantic Ocean also plays an important role in this misattribution. To complicate things even more, although the Turkish governance in the Arabian Peninsula had ceased in the seventeenth century and the control of the region reverted to its Bedouin chiefs, ${ }^{66}$ local identities were still in flux,

65 Janice J. Terry, Mistaken Identity: Arab Stereotypes in Popular Writing (Washington: American-Arab Affairs Council, 1985), 8.

66 In 1663, the Ottoman governor of Al Hassa in the Arabian Peninsula was overthrown and a reform movement headed by Muhammad ibn 'Abd al-Wahhab of Najd started. He entered an alliance with Muhammad ibn Sa'ud and participated in several raids in Iraq. The Sa'uds then made inroads into Oman, Muscat, Bahrain, the southern Persian coast, and East Africa and eventually signed a treaty with the British East India Company (1798) to counter the growing threat of the Wahhabis. 
Arabs from the Peninsula being often perceived as being under the influence of the Ottoman Empire. Finally, another reason for this misattribution is cultural: it lies in the power of a text inadvertently translated in England as Arabian Nights' Entertainments. This Grub Street translation of Galland's translation of One Thousand and One Nights was an instant success, being insistently republished, pirated, enlarged, adapted, and reimagined throughout the century. ${ }^{67}$ However, although coined "Arabian," the collection contained very few tales that were actually Arabic in origin. Arabian Nights' Entertainments is a composite collection of stories with roots in India, Persia, Iraq, Egypt, Turkey, Greece, and even China (as is the case of Aladdin's famous tale), which clearly reflect the folklore of their place of origin. Little of this complicated history of the manuscript used for this translation was known at the time, ${ }^{68}$ hence the subsequent emergence and solidifying of false stereotypes about "Arabs" and all things "Arabian."

The Ottomans regained control of the Arabian Peninsula in the nineteenth century but their suzerainty was mainly nominal. Arabia was freed from Ottoman control in 1918. See Albert Hourani, A History of the Arab Peoples (London: Faber \& Faber, 2005), esp. 315-19.

Some of the works inspired by Arabian Nights' Entertainments include: Richard Johnson, The Oriental Moralist or the Beauties of the "Arabian Nights Entertainments," trans. Rev. Mr. Cooper (London: Printed for E. Newbery, 179o?); Arabian Tales. Being a Continuation of the "Arabian Nights Entertainments." Consisting of One Thousand and One Stories, Told by the Sultaness of the Indies, to Divert the Sultan from the Execution of a Bloody Vow He Had Made, to Marry a Lady Every Day, and Have Her Cut off Next Morning, to Avenge Himself for the Disloyalty of His First Sultaness... (Edinburgh: Printed for G. Mudie et al., 1792); and William Bond, The Fortunate and Unfortunate Lovers; or, The Histories of Dorastus and Fawnia, Hero and Leander, or, New Arabian Tales (Dublin: Printed by W. Jones, 1793).

For a detailed history of the origins of this book, see Robert Irwin, "The Book without Authors," in The Arabian Nights: A Companion (London: Tauris Parke Paperbacks, 2005), 43-62.
Many of the stereotypes emerging from Arabian Nights' Entertainments rely on very specific things that consistently suggest excess, beauty, wealth, luxury, and magic. The beauty of a woman, for instance, is enhanced by her wearing "flower'd Satin ... with Pendants in her Ears, a Necklace of large Pearl, and Bracelets of Gold, garnished with Rubies." ${ }^{9}$ The "great Halls" of the Sultan's palace are "hung with Silk Tapestry, the Alcoves and Sofas [a]re covered with Stuffs of Mecca, and the Porches with the richest Stuffs of the Indies, mixed with Gold and Silver." ${ }^{\prime 0}$ The "admirable Saloon" where Scheherazade tells her stories has "a great fountain" in the middle, "with a lion of massy Gold at each corner: Water issued at the mouths of the four Lions and this Water ... form'd Diamonds and Pearls."71 A case "cover'd with yellow Satin, richly embroidered with Gold, and green Silk"72 is used to shelter a lute used to accompany a lover's song. Opening the "fatal Door" to a forbidden chamber, Dinarzade steps on a pavement "strew'd over with Saffron," discovers "several candlesticks of massy Gold, with lighted Tapers that smell'd of Aloes and Ambergreese," sees "Lamps of Gold and Silver that burnt with Oil made of several sorts of sweet scented Materials,"73 and then is kidnapped by a winged horse. During his voyages, Sinbad is presented with such rarities as "Aloes, Sanders, Camphire, Nutmegs, Cloves, Pepper and Ginger,"74 walks through a valley "strew'd with Diamonds ... of a surprising bigness" which is guarded by serpents "so long that the least of

69 I use here the 12-volume edition of Arabian Nights' Entertainments: Consisting of One Thousand and One Stories. Told by the Sultaness of the Indies, to Divert the Sultan from the Execution of a Bloody Vow He Had Made to Marry a Lady Every Day, and Have Her Cut off Next Morning, to Avenge Himself for the Disloyalty of His First Sultaness..., 7th ed. (Dublin: Printed by S. Powell et al., 1728), 1:66. Ibid., 1:63. Ibid.

Ibid., 2:14.

Ibid., $2: 84$.

Ibid., 3:119. 
them was capable of swallowing an Elephant,"75 and encounters Roc, a "bird of a monstrous size."76 King Saleh's purse is filled with "three hundred Diamonds, as large as Pigeons' eggs; a like Number of Rubies, of extraordinary Size; as many Emerald Wands of half a foot long; and with thirty Strings of Necklaces of Pearl, consisting each of ten pieces." ${ }^{77}$ When rubbed by its owner, Aladdin's magic lamp releases "a hideous Genie of a gygantick Size"78 that fulfills all his wishes (fig. 4.8). A Dervish lights a fire and casts in it a magic perfume that opens the doors to a magnificent Palace "built in the hollow of a Rock"79 and hiding an inconceivable treasure. The Prince of Samaria has a "white horse who had a Gold Bit and Shoes, his Hoofing was of Blew Sattin, embroder'd with Pearls; the Hilt of his Cimiter was of one entire diamond, and the Scabbard of Sandal-Wood, all adorn'd with Emerauds and Rubies." 80 Princess Neuronnibar is courted with such rarities as a tapestry that may transport the holder in an instant "wherever he desires to be," an "Ivory Prospective Glass," and an "artificial Apple." 1

A few conclusions can be drawn from this quick sampling of the things that fill the pages of the Arabian Nights. First, when juxtaposed to the bareness of Arabia described by many of the travel narratives of the time, the things that make this phantasmatic Arabia have an obvious magical quality. As Bill Brown correctly put it, "[w]e begin to confront the thingness of objects when they stop working for us; when the drill breaks, when the car stalls, when the window gets filthy, when their flow within the circuits of production and distribution, consumption and exhibition, has been

$\begin{array}{ll}75 & \text { Ibid., 3:122. } \\ 76 & \text { Ibid., 3:121. } \\ 77 & \text { Ibid., 7:85. } \\ 78 & \text { Ibid., 9:300. } \\ 79 & \text { Ibid., 10:83. } \\ 80 & \text { Ibid., 8:197. } \\ 81 & \text { Ibid., 12:206-16. }\end{array}$

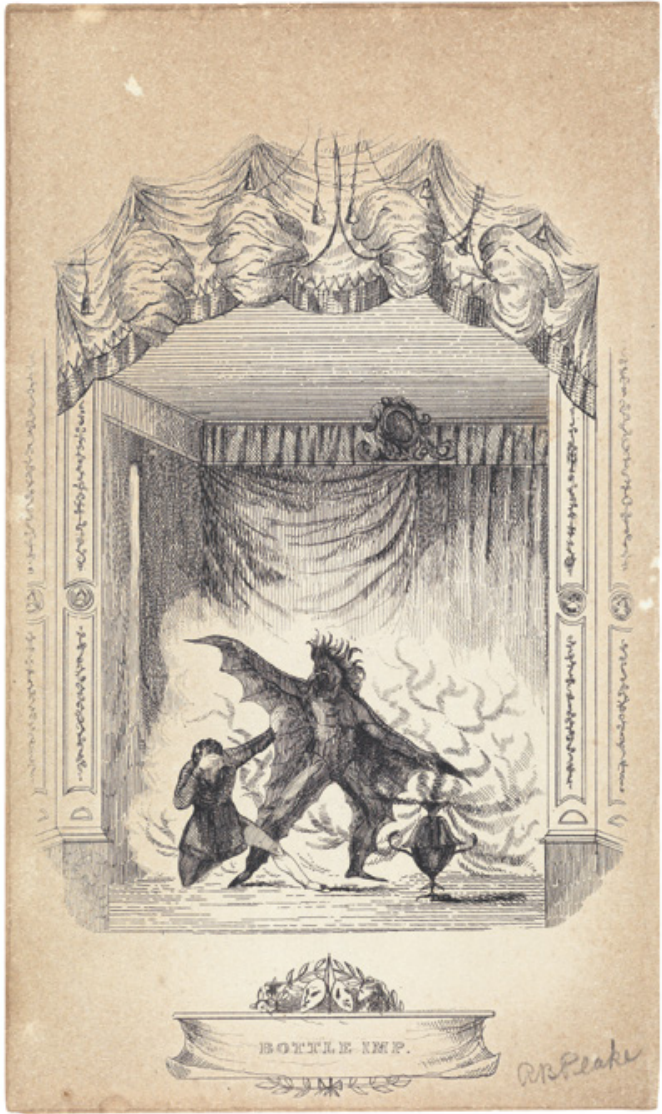

FIGURE 4.8 The Bottle Imp. Lewis Walpole Library's Collection of Eighteenth-Century Theatrical Prints.

arrested, however momentarily" 82 [emphasis added]. In the case of the Arabian things, however, this thingness becomes evident when the things start working for us in a way that exceeds their normal abilities to perform. Magic becomes, thus, a way of accessing an other place, one in which "the virtues of things" are united "through the application of them one to the other." ${ }^{83}$ Within this fictional realm, the things of "Arabia" gain an agency of their own: perfumes split mountains in two, lamps fulfill a subject's wishes, horses can fly, and

\footnotetext{
82 Bill Brown, "Thing Theory," Critical Inquiry 28, no. 1 (2001): 3 .

83 Henry Cornelius Agrippa, Three Books of Occult Philosophy or Magic (Whitefish, MT: Kessinger Publishing, 2010), 35 .
} 


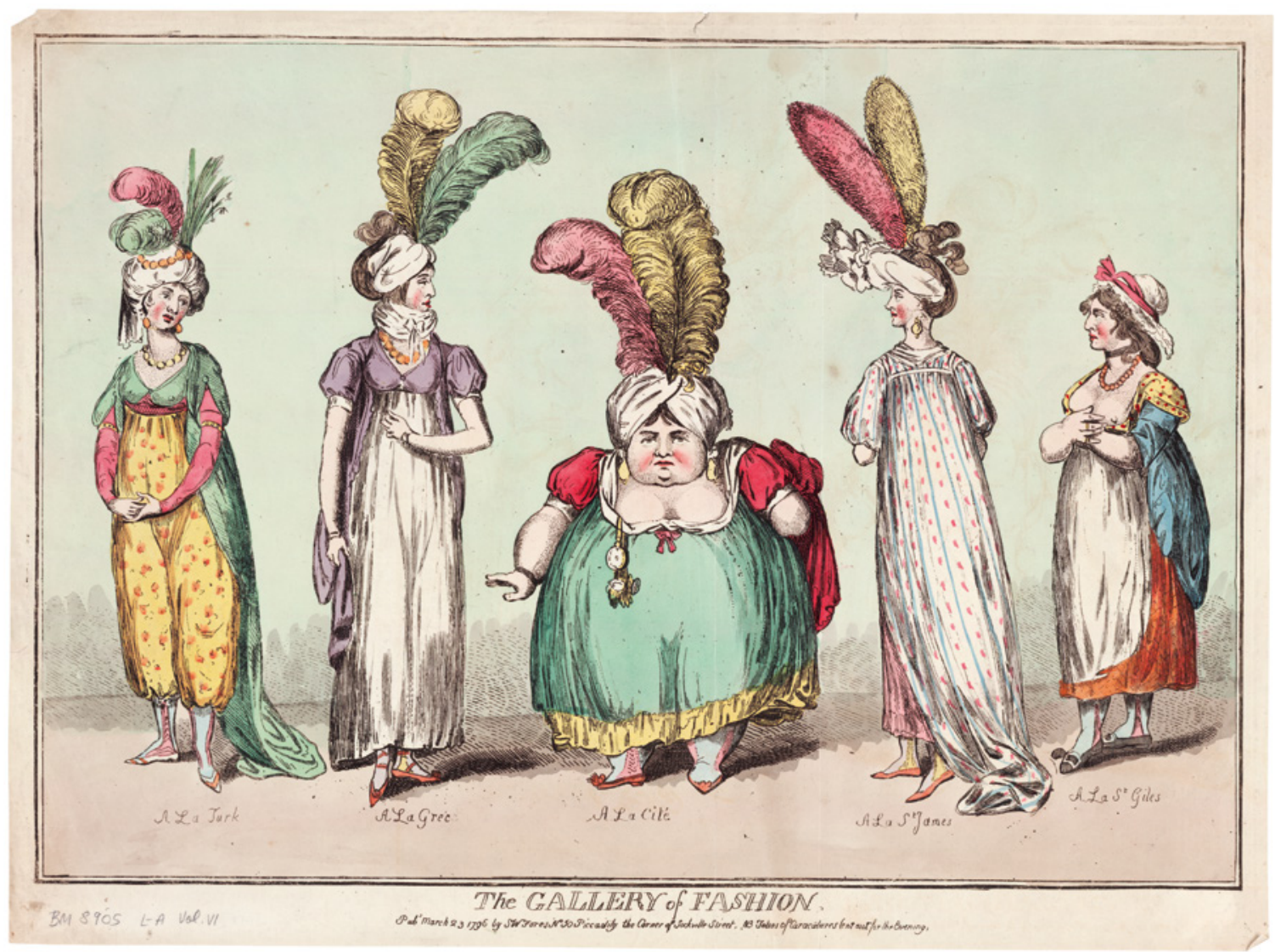

FIGURE 4.9 Isaac Cruikshank, The Gallery of Fashion [graphic]. Etching on wove paper, hand-colored. PUBLISHED BY S.W. FORES, LONDON, 1796

tapestries have transporting qualities. At other times, the extraordinariness of these objects is enhanced by the soft music and faded lights that blur their contours, placing them somewhere between reality and fantasy_-a realm of magical materialism which, although strikingly different from that of European rationalism, bears, nevertheless, positive connotations of desirability, curiosity, and imaginative gratification.

Following this translation, Orientalist narratives started to proliferate and supernatural things of Oriental origin entered the theater, opera, pantomime, and, later in the century, children's literature, being absorbed in the Western culture for their ability to expand the limits of one's imagination and because, simply put, magic sells. Such things became part of an Orientalist narrative whose fantasy is, indeed, a form of desire, but not necessarily one for conquest and appropriation: rare or supernatural things are but a way of filling the spaces of the Near East with things of the imagination that make the unknown knowable and fuel dreams of power unbound by one's limited human abilities.

Within this narrative, tropes of affluence, pleasure, and excess are repeatedly employed, aggrandizing the place and enveloping it in an aura of danger and adventure whose attraction is impossible to resist. However, the things that describe Arabia stand out not only for their excessive size or number but also for their exquisite quality, beauty, and power. Gold, silver, diamonds, rubies, emeralds, and pearls become the raw material of everyday life, giving ordinary things an extraordinary expression 


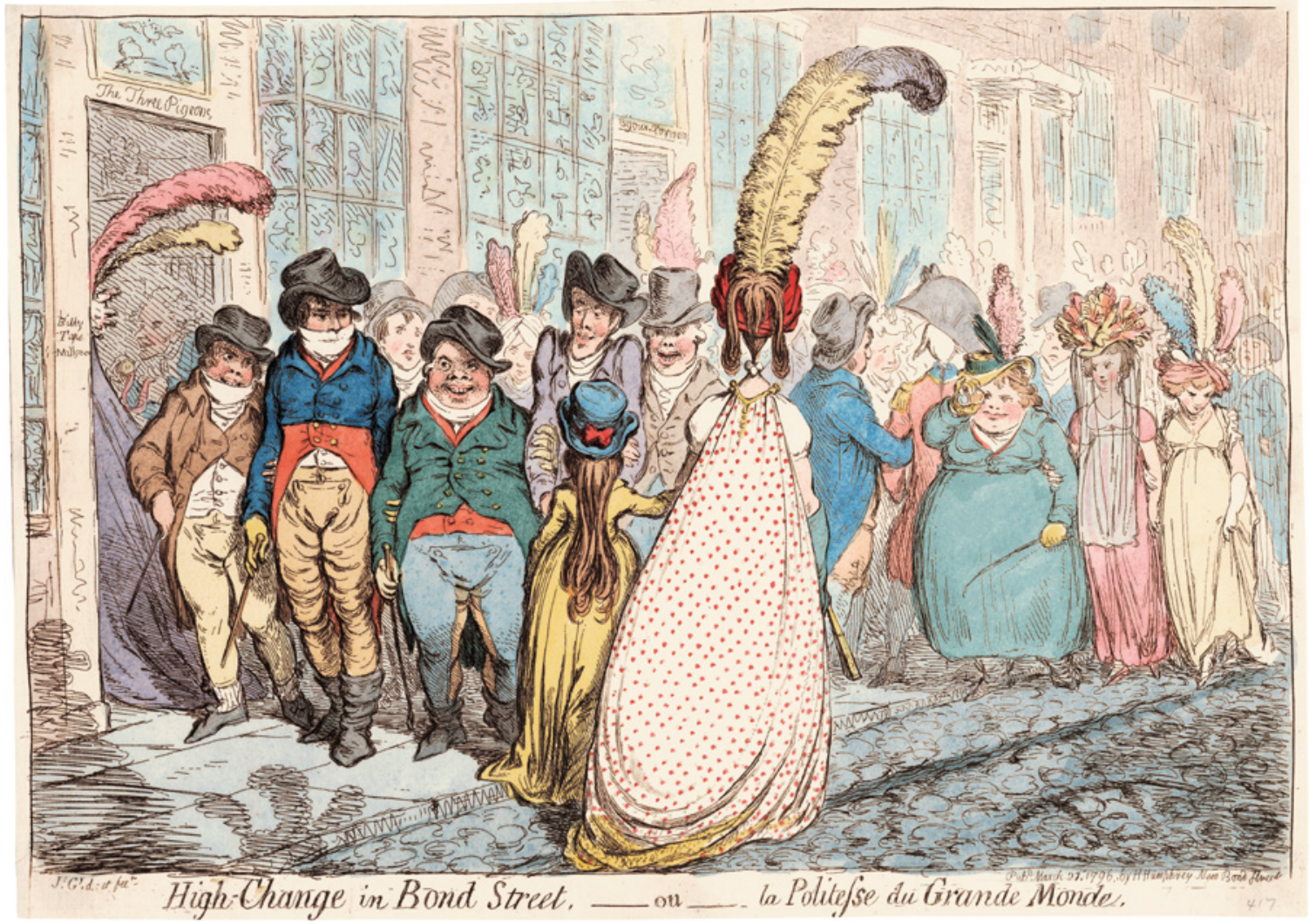

FIGURE 4.10 James Gillray, High Change in Bond Street; ou la politesse du grande monde [graphic]. Etching on wove paper, hand-colored.

PUBLISHED BY H. HUMPHREY, LONDON, 1796

meant to bewilder the viewer. Satins, silks, ivory, gigantic eggs, and "artificial" apples describe, in fact, the things of the trade: expensive and rare fabrics, on the one hand, strange collectibles and exotica, on the other. Lavish dresses and embellishments become insignia of wealth, power, and nonconformity, of a way of life outside the economic constraints of the Western civilization. Interestingly, such projections were internalized by eighteenth-century British subjects in the fashionable "Turquerie" that allowed the wearers to display their wealth by wearing Oriental dress, turbans, ostrich plumes, long capes, veils, and flattering shalvars (figs. 4.9 and 4.10). Another infusion of Orientalism in the West, the tradition of painting European figures in Middle Eastern dress, becomes a form of cultural cross-dressing meant to suggest misuse of power or excessive wealth (fig. 4.11). Such cultural imports are difficult to be understood, to use Said's qualification, as expressions of the Occident's cultural "antipathy" ${ }^{84}$ toward the Orient; rather, they reflect the West's attraction to a space that connotes difference understood as extraordinariness rather than inferiority.

Besides their connotations of magic, exoticism, and wealth, the things in the Arabian Nights are also rich bearers of cultural information: as Marina Warner correctly pointed out, "stories are lodged in goods" 85 and as such, they expand the reader's

\footnotetext{
84 Said, Orientalism, 260.

85 Marina Warner, introduction to Stranger Magic: Charmed States and the Arabian Nights (London: Chatto \& Windus, 2011), 8.
} 


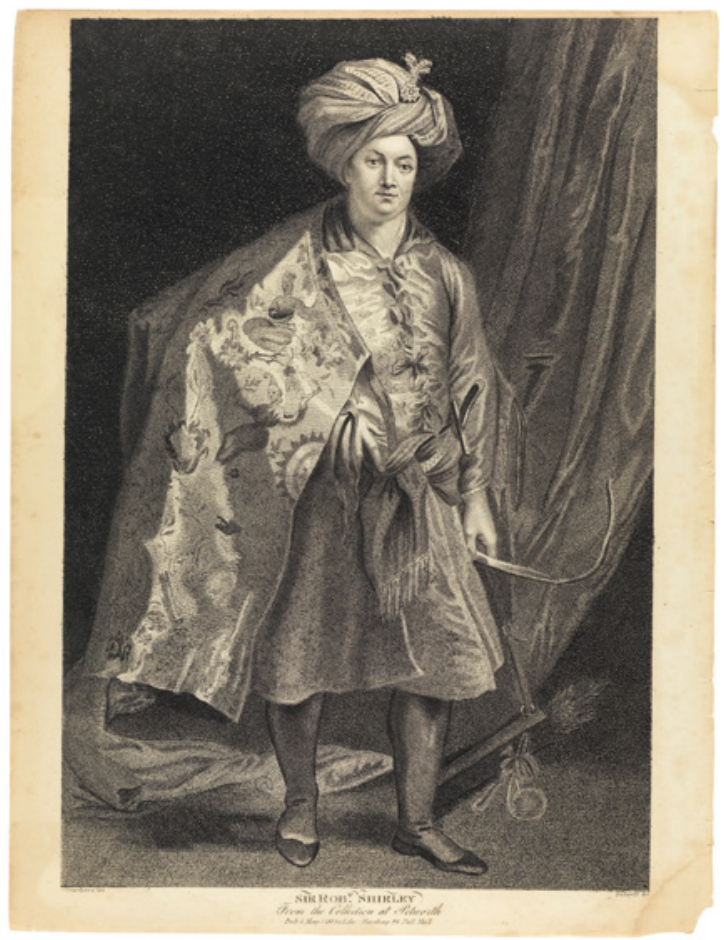

FIG URE 4.11 A. Birrell, Sir Robert Shirley [graphic]. Engraving on wove paper.

PUBLISHED BY EDWARD HARDING, LONDON, 1799

knowledge about remote civilizations. There is an obvious cultural coincidence, for instance, between carpet-making and storytelling among nomadic peoples, which these stories convey through their intricate plot development. They also tell fascinating stories about the the traffic in diamonds, gold, and spices between the Indies, China, Arabia, and Western Europe that still wait to be unveiled. Rather than looking at the things of the Nights as colorful details in Sheherazade's tales or protagonists in the fantastic stories they make for themselves, we could explore, instead, their role as as bearers of cultural knowledge unintentionally embedded in the fabric of the text. In such a reading, "historically and theoretically overdetermined material charactersitics of objects are sought out beyond the immediate context in which they appear" 86 in order to

86 Elaine Freedgood, "Introduction: Reading Things," in The Idea in Things: Fugitive Meaning in the Victorian Novel (Chicago: University of Chicago Press, 2006), $5^{-6 .}$ defetishize them and expose the power structures in which they are involved.

Thus, as Makdisi and Nussbaum sum up in their introduction to The Arabian Nights in Historical Context: Between East and West, "the Nights offered a particularly powerful vision of an Asiatic culture seemingly saturated with references to sensuality, extravagance, indulgence, violence, supernaturalism, and eroticism ... [and] added a supernatural dimension to the Enlightenment; the tales offered an avenue into modernity through its magical opposite, an alternative to European identity, and an antidote to neoclassicism." ${ }^{87}$ However, reading such imports as an expression of European powers' disavowal of the East in order to "justify their conquest and rule over other peoples, particularly in Asia," 88 is an oversimplification of a rather complicated process of cultural exchange. None of these descriptions of Arabia were caused by colonial "distortions," as Said feared, but by false attributions: "Arabian" was a misnomer that rarely described Arabia itself. While fictional narratives like Arabian Nights' Entertainments represented Arabia as a land of magic and exorbitant riches, they were too far-fetched to be part of a Westerner's belief system during the Age of Reason; rather, they were popularized because their wild fictionality turned them into bestsellers at the time. Such stories competed with descriptions of the Arabian Peninsula by travelers and traders who had visited the area and had unmediated contact with the local culture. However, while the Orientalist literature described Arabia in terms that emphasized its exoticism, magic, superstitions, extravagance, wealth, eroticism, excess, and myriads of other peculiarities that contrasted it with the European normativity, travel narratives created an "Arabian" identity that was generally congruent with the reality of the place.

87 Makdisi and Nussbaum, introduction to The Arabian Nights in Historical Context, 5 . 


\section{3}

\section{Arabian Stereotypes}

Arabia's box of wonders contains things that create a mental picture of the place with highly distinctive characteristics. The stereotypes associated with the Arabian Peninsula during the eighteenth century generated from merchants and travelers who documented their trips to the dangerous deserts of Arabia, and were recycled in the instructional, entertaining, and literary productions of the time in ways that subtly altered the stereotype to reflect the authors' intentions. Arabia's things range from spatial landmarks (deserts, sands, oases, palm trees) to commodities (spices, perfumes, coffee, dates, tobacco, pearls, ivory, gold) to animals (camels, horses, goats, sheep) to slaves. ${ }^{89}$ They describe a space both hostile and alluring, barren and fertile, poor and lavish, deserted and extravagant. Its undisputable exoticism is a play of contraries that simultaneously signify danger and heavenly bliss. In this landscape, the source of a thing's value is, as Georg Simmel correctly put it, not the productive labor, but the subject's desire. ${ }^{90}$ Depending on who writes the account, the object reflects a variety of projections meant to highlight its commercial value, exoticism, luxury status, or fictional power. The things of Arabia circulate outside their place of origin on commercial routes that enrich the Western world but at the same time bear with them narratives of affluence, danger, and desire whose traces can still be found in our culture today.

In "The Other Question. Stereotype, Discrimination and the Discourse of Colonialism," Homi Bhabha defines the stereotype though a postcolonial lens as part of "an apparatus of power which contains an other knowledge," "an arrested, fixated form of representation that, in denying the play of difference, constitutes a problem for the represen-

\footnotetext{
89 For references to "Christian slaves," see A Collection of Voyages and Travels, 509, 620, et alia.

$90 \quad$ Simmel on Culture: Selected Writings, ed. David Frisby and Mike Featherstone (London: Sage Publications, 1997), 37.
}

tation of the subject." ${ }^{11}$ Here, Bhabha calls attention to the inherent ambivalence of the colonial stereotype, which encapsulates various racial, cultural, and historical differences: "rather than a false image which becomes the scapegoat of discriminatory practices," the stereotype is a text of "projection and introjection, metaphoric and metonymic strategies, displacement, overdetermination, guilt, aggresivity; the masking and splitting of 'official' and phantasmatic knowledges to construct the positionalities and oppositionalities of racist discourse." ${ }^{\prime 2}$ What is left, concludes Bhabha by quoting one of Fanon's memorable sententia, is "on the one hand a culture in which qualities of dynamism, of growth, of depth can be recognized" and, on the other hand, colonial cultures in which "we find characteristics, curiosities, things [emphasis added], never a structure." ${ }^{\prime 3}$

Such qualifications should give us pause. As simplified "pictures in our head," stereotypes involve a process of selection that places objects and events into conceptual categories to help us navigate an object- and subject-packed reality. They are part of a normal cognitive process that requires simplification, categorization, intuitive thinking, and indiscriminate adoption of "what our culture has already defined for us." ${ }^{94}$ As such, they fulfil three fundamental human needs: the need to be efficient, promote feelings of self-worth, and justify the social structure. ${ }^{95}$ Through processes of anchoring (classifying the unfamiliar in terms of what is known) and objectification (processing

\footnotetext{
91 Homi K. Bhabha, The Location of Culture (London: Routledge, 1994), 75 .

92 Ibid., 34 .

93 Ibid., 84. Bhabha cites here from Frantz Fanon's speech, "Racism and Culture," published in Toward the African Revolution, trans. Haakon Chevalier (London: Pelican, 1970), 44. Walter Lippmann, Public Opinion (New York: Free Press Paperbacks, 1997), 55.

95 Steven J. Sherman, Jeffrey W. Sherman, Elise J. Percy, and Courtney K. Soderberg, "Stereotype Development and Formation," in The Oxford Handbook of Social Cognition, ed. Donald E. Carlston (Oxford: Oxford University Press, 2013), 564 .
} 
ideas about places or individuals into an "objective," socially-constructed reality), ${ }^{96}$ stereotypes help us create social identities based on existing knowledge and involve comparison, contrast, and interpretation. So, are they, indeed, inaccurate, or distorted views of reality? When we think about "Arabia," just like Johnson did, as a "sandy desert" crossed by caravans, is this mental picture a bearer of slanted cultural representations? Is Alexander Pope's description of Arabia in terms of its perfumes, or the recurrent mention of its spices, coffee, sweets, or aromatic tobacco in travelers' reports or in the eighteenth-century literary imagination a symptom of a culturally-constructed superiority complex? Are "the women dressed in haiks, the palm groves and the camels" just "the natural backdrop" of the civilizing West, as Fanon described them ${ }^{97}$

I fear that such interpretations stereotype the stereotype even more. They simplify a rather complicated cognitive process of cultural representation and, even worse, read the stereotype as necessarily distorted, rigid, biased, divisive, and politically incorrect. Of course, such approaches may make sense in postcolonial readings of the non-European other as not only different but less than his or her European counterpart, and lesser in a racially-, ethnically- or culturally-constructed hierarchy. Such representations, however, do not work well when qualifying the West's depictions of the Arabs or Arabia, as this chapter extensively illustrates: during the eighteenth century, the stereotypes associated with the area contained strong tropes of desirability, adventure, and wealth rather than subjectification and scapegoating. The "consensual universe," or socially-constructed image of "Arabia" that these stereotypes depict aligns well

96 Serge Moscovici, "The Phenomenon of Social Representations," in Social Representations, ed. Rob M. Farr and Serge Moscovici (Cambridge: Cambridge University Press, 1984), 28-43.

97 Frantz Fanon, The Wretched of the Earth, trans. Richard Philcox (New York: Grove Press, 2004), 182. with the "reified universe" of positivist knowledge ${ }^{98}$ when stereotypes focus on the things that stand for the place-that is, "when the criteria [a]re objective"99 _ and not on conflicting ideologies. While some stereotypes may bear negative connotations, not all of them do, and they all have some degree of accuracy. ${ }^{100}$

But Bhabha's definition of otherness as "at once an object of desire and derision"101 [emphasis added] is highly significant not only for its implications of racial and cultural marginalization but also because it refers to the other as an object in a way that makes the object an undesirable encapsulation of the subject. I argue, instead, that the things things say matter and that the object's relation with the subject should not necessarily be one of subordination but of mutually informing coexistence. I echo here Latour's defense of the nonhuman actors as indispensable to a correct understanding of the very nature of societies through a network-like ontology. ${ }^{102}$ Instead of speculating on the politics of the object, or on its diminished value when compared with a subject, we may better consider the networks of relations-commercial, cultural, emotional- that make the humans and non-humans partners in an expanding, inclusive, nonhierarchical network of relations. In this sense, during the eighteenth century, the things of Arabia participated in an active process of identity

98 Moscovici, "The Phenomenon of Social Representations," 19-23.

99 Lee J. Jussim, Jarret T. Crawford, Stephanie M. Anglin, John R., Chambers, Sean T. Stevens, and Florette Cohen, "Stereotype Accuracy: One of the Largest and Most Replicable Effects in All of Social Psychology," in Handbook of Prejudice, Stereotyping, and Discrimination, ed. Todd D. Nelson (New York: Psychology Press, 2016), 41.

For a compelling defense of stereotypes, see also Stereotype Accuracy: Toward Appreciating Group Differences, ed. Yueh-Ting Lee, Lee J. Jussim, and Clark R. McCauley (Washington, DC: American Psychological Association, 1995).
Bhabha, The Location of Culture, 67.

Latour, "On Actor-Network Theory," 370. 
formation, representing the Arabs to other cultures while circulating outside their place of origin.

By reading a space in terms of its things depoliticizes the discourse and legitimizes the stereotype by shifting attention to its intrinsic accuracy: as social representations, stereotypes "are not a product of a failure to think 'properly,' or a distortion. Rather, they evolve out of the communication within a social group which objectifies and legitimizes the social knowledge of the group."103 We still think of Arabia in terms of its spices, coffee, or aromatic oils; even more, the Arabs of the Peninsula themselves have internalized Orientalized representations that emphasize the lure and mystery of the place. When visiting Abu Dhabi's Official Visitor Website, for instance, tourists are invited to a "once-in-a-lifetime experience" of pearl journey aboard a pearling dhow, where they are "seated on traditional Arabian floor cushions" and enjoy "locally-made Arabic coffee and dates." Alternately, visitors are invited to explore "the desert expanse ... [with] high dunes and long sand valleys" outside the Liwa oasis, where they can practice dune bashing, sand skiing, camel

103 Perry R. Hinton, Stereotypes, Cognition and Culture (Hove: Psychology Press, 2000), 158. riding, and have "a traditional meal under the stars." In the Empty Quarter, "the magnificent Qasr Al Sarab or Mirage Palace is a luxurious oasis in the midst of the desert" whose beauty is reminiscent of "a fairytale from '1001 nights."'104 Such things have become, through ongoing processes of cultural and commercial exchange, strong identifiers of the place. In turn, the stereotypes associated with them reflect a form of knowledge that, while embellished or refined during its circulation, is still based on a distant origin of truth. In this case study, the correlation between the beliefs we hold about "Arabia" and the criteria against which we measure them is high because things don't lie. Things describe a subject or a place without bias, disseminate information through their networks of commercial exchange, and shape our cultural imaginary as bearers of distilled truth. By following their trajectories, Arabia will become less different, less alien, and less threatening, and will start to signify, as we all hope, a new thing altogether.

\footnotetext{
104 Abu Dhabi's Official Visitor Website for Travel \& Tourism Information. Visitabudhabi.ae. https://visitabudhabi.ae/ae-en/default.aspx (accessed September 1, 2018).
} 